\title{
A stressz hatása a szóbeli nyelvi közvetítés minőségére tolmácsvizsgákon
}

\author{
Besznyák Rita \\ E-mail: besznyak.rita@inyk.bme.hu
}

\begin{abstract}
Kivonat: Tolmácsolás közben a nyelvi közvetítés minőségére számos tényező hatással van - a tolmácsnak gyakran változó és kiszámíthatatlan körülmények között kell magas színvonalon teljesítenie, hiszen a kommunikáció sikere múlhat rajta. Mindez komoly stressz-terhelést jelent a tolmácsok számára, ami kétségtelenül rányomja a bélyegét a nyelvi közvetítés minőségére is. Különösen igaz ez a tolmácshallgatók esetében, akiknek a képzésük lezárásaként vizsgán kell számot adniuk az elsajátított ismeretekről és készségekről. Ez a kétszeresen is stresszes helyzet ideális lehetőséget nyújt annak feltérképezésére, hogy a stressznek - az általában vizsgált fiziológiai tüneteken túl - milyen hatása van a nyelvi közvetítés minőségére. Ezt a kutatási célt szem előtt tartva a tanulmány először áttekinti azokat a tényezőket, melyek alapján megítélhető a tolmácsolás minősége, majd számba veszi azokat a külső és belső változókat, melyek hatással lehetnek a tolmács teljesítményére. Ezen belül is kiemelt hangsúlyt kapnak a tolmácsolandó szöveg nehézségét meghatározó tényezők és a stresszfaktor. A teljesítményszorongásból fakadó esetleges minőségromlás konkrét megnyilvánulásainak felderítéséhez a tanulmány harmadik felében összegzem azokat a szempontokat, amelyek a tolmácsteljesítmény értékelésénél megjelennek vizsgahelyzetben. A tanulmány végén röviden kitérek arra is, hogy az eddigi kutatások fényében milyen lehetséges kutatási irányok körvonalazódnak a jövőre nézve.
\end{abstract}

Kulcsszavak: tolmácsolás minősége, input változó, stressztényező, tolmácsvizsga, értékelés

\section{Bevezetés}

Széleskörü empirikus kutatások nélkül is bátran kijelenthetjük, hogy a tolmácsolás igen stresszes tevékenység. Ahogy arra a tolmácsolástudományban talán legtöbbet idézett szerző, Daniel Gile is rámutat, „a tolmácsoknak folyamatosan váratlan helyzetekben kell helytállniuk, miközben eleve rendelkezésre álló

Hivatkozás: Besznyák R. 2019. A stressz hatása a szóbeli nyelvi közvetítés minőségére tolmácsvizsgákon. Fordítástudomány 21. évf. 2. szám. 80-100.

DOI: https://doi.org/10.35924/fordtud.21.2.6 
feldolgozási kapacitásuk határán dolgoznak" (Gile 1995:161, a szerző fordítása). Igen komplex kognitív múveletek alkalmazásával kell valaki másnak a gondolatait közvetíteniük, lehetőség szerint hủen és követhetően, tartalmilag és formailag egyaránt pontosan - mindezt változó munkakörülmények és magas szintű minőségi elvárások között.

Ahhoz sem kell nagyon elmélyednünk a vonatkozó szakirodalomban, hogy megállapíthassuk, a vizsgázás is igen stresszes tevékenység. A stressz egyik sajátos, ám hétköznapi szinten is gyakran megnyilvánuló formája a számonkérési helyzetekben jelentkező teljesítményszorongás, amely - ha nem kezelik megfelelően - jelentősen leronthatja a vizsgán nyújtott teljesítményt. Mindegy, hogy a megszerzett tudásanyagról vagy az elsajátított készségekről kell számot adnunk az adott vizsgahelyzetben, a stresszfaktor komoly megterhelést jelent, ami sok esetben fiziológiai tünetekben is jelentkezik (vö. Sarason 1950, Klonowicz 1994, Kurz 2002).

Ez a két komoly stresszterhelést jelentő tevékenység egyesül a tolmácsképzéseket lezáró kimeneti vizsgákon, s pont ebben a hatványozottan stresszes alaphelyzetben kell a tolmácshallgatóknak tudásuk legjavát nyújtaniuk. A képesítésük múlik azon, hogy a vizsgabizottság tagjainak értékelése alapján a teljesítményük megfelel-e az adott intézményben elvárt kimeneti követelményeknek. A tolmácsoknak munkájuk során gyakran kell nyomás alatt jól teljesíteniük, de vajon milyen teljesítményt tekinthetünk elfogadhatónak egy pályája legelején álló kezdő tolmácsnál? Alkalmazhatóak-e maradéktalanul ebben a különösen stresszes helyzetben is azok a minőségi elvárások, melyeket a tolmácsoláskutatók évtizedek óta igyekeznek váltakozó súlypontokkal minél pontosabban definiálni (vö. Bühler 1986, Pöchhacker 1994, Moser-Mercer 1996 és Kalina 2002, 2005).

A vonatkozó szakirodalomban gyakran olvashatunk arról, hogy a minőség a tolmácsolásban nem abszolút fogalom, mást és mást jelent a folyamatban érintett egyes szereplőknek, s nagyon nehéz általános érvényű standardokat felállítani (Moser-Mercer 1996, Kahane 2000). A képzőintézmények mégis arra vállalkoznak, hogy több nézőpontot egyesítve értékelik a tolmácshallgatók teljesítményét egységes, és lehetőség szerint objektív szempontok alapján. Az értékelés történhet holisztikus vagy analitikus megközelítésben, optimális esetben az analitikus vizsgálatok eredményei alátámasztják a holisztikus benyomásokat (vö. Barik 1975, G. Láng 2002, Setton és Dawrant 2016). Ahhoz, hogy tisztán lássuk, mely forrásszövegek alkalmasak vizsgahelyzetben az elsajátított kompetenciák tesztelésre, számba kell venni azokat a tényezőket, amelyek a tolmácsolás minőségét befolyásolhatják: a külső környezeti változókat (vö. Pöchhacker 2004, Mead 2015), a tolmácsolt beszédek nehézségi fokát (vö. G. Láng 2002, Setton és Dawrant 2016), az elvárt kompetenciák meglétét (vö. AIIC 1994, Daró 1994, Moser-Mercer 1994, Kalina 2002) és a stresszfaktor hatását tolmácsolási helyzetben (vö. Cooper et al 1982, AIIC 2002, Horváth 2015).

Többen vizsgálták már a stressz típusait, fiziológiai tüneteit, lehetséges negatív és pozitív hatásait a tolmácsolási teljesítményre (vö. Moser-Mercer et al. 1998, Kurz 2002, Boronkay-Roe 2006), ám a nyelvi közvetítés minőségében 
megmutatkozó hatását vizsgahelyzetben még egyetlen kutatás sem dolgozta fel analitikus eszközökkel. Pedig kutatói szemmel ez a „duplán stresszes” tolmácsolási helyzet ideális lehet annak felmérésére és nyelvészeti megközelítésü elemzésére, hogy milyen hatással van a stressz-tényező a tolmácsolás minőségére. Ráadásul azért is kívánatos lehet a vizsgán nyújtott tolmácsolási teljesítmény analitikus szemléletű nyelvészeti elemzése, mert - adaptálva Klaudy Kinga szóhasználatát a szakfordítói vizsgák leírására (Klaudy 2005:77) - a záróvizsgán a „diagnosztikus célú értékelésnél” is feltétlenül szükség van a hibák megnevezésére és súlyozására a hallgatóknak adott visszajelzés és a vizsgáztatók számára kidolgozott egységes értékelési irányelvek miatt. Ha sikerül kimutatni, hogy milyen tartalmi és formai hibák jelentkeznek nagyobb arányban a stressz hatására tolmácsolási vizsgahelyzetben, az nagyban segítheti a vizsgakészülést és a vizsgafeladatok optimalizálását.

Jelen tanulmányomban elsősorban a témához kapcsolódó szakirodalom legfontosabb megállapításait összegzem három részkutatási terület eddigi eredményeit bemutatva. E három terület a következő: (1) a minőség fogalma és minőségbiztosítási törekvések a tolmácsolásban; (2) a tolmácsolás minőségét befolyásoló nyelvi és nyelven kívüli tényezők, különös tekintettel a szövegnehézséget meghatározó szempontokra és a stressztényezőre; és (3) a tolmácsteljesítmény mérése és értékelése a tolmácsképzésben. A szakirodalmi áttekintést követően röviden kitérek arra is, hogy az eddigi kutatások fényében milyen lehetséges kutatási irányok körvonalazódnak a jövőre nézve.

\section{A minőség fogalma és minőségbiztosítás a tolmácsolásban}

A tolmácsolással kapcsolatban az 1980-as évek közepén merült föl először szisztematikus igényfelmérések szintjén a minőségbiztosítás kérdése - elsősorban Hildegund Bühler kutatása nyomán, aki a Konferenciatolmácsok Nemzetközi Szövetségének (AIIC) tagjai körében végzett felmérést a tolmácsokkal szemben támasztott elvárásokról (Bühler 1986). Közel tíz évvel később, 1995-ben készült el annak az átfogó AIIC-felmérésnek az eredménye, amelyben Peter Moser valós tolmácsolási helyzetekben a tolmácsok és a felhasználók szempontjait és elvárásait egyaránt figyelembe véve rendszerbe foglalta a minőségbiztosítási szempontból releváns tényezőket (Moser 1995).

A legtöbb, a tolmácsolás minőségét mérni, számszerüsíteni próbáló kutatás végső soron arra jutott - amit Eduardo Kahane Thoughts on the Quality of Interpretation c. összefoglaló tanulmányában meg is fogalmazott (Kahane 2000) -, hogy a sok változó tényező miatt igen problematikus a tolmácsolási teljesítmény objektív megítélése. Mást vár el a megbízó, más teljesítményt tart elfogadhatónak egy tolmács-kolléga, és máshogy látja magát belülről a tolmács. Az érintett szereplők más-más szempontok alapján ítélik meg a tolmácsolás minőségét, eltérő prioritások jelennek meg a megbízók, a vizsgáztatók, a tolmácsolás-kutatók, illetve a felhasználók értékítéletében (vö. Moser-Mercer 1996).

A tolmács nyelvi, terminológiai, interkulturális felkészültségén, stressztürésén és alapvető tájékozottságán túl a teljesítményét nagyban befolyásolja pél- 
dául a felkészülési anyagok hozzáférhetősége, az előadó személyisége és előadói képességei, a téma komplexitása és a technikai feltételek. A tolmácsteljesítmény megítélése és minősítése tehát csak adott helyzetben, adott időben, adott körülmények között értelmezhető, nincsenek általános érvényủ minősítési kritériumok. Az értékelés gyakran intuitív módszerekkel, szubjektív szempontok alapján történik, hiszen a szóbeli közvetítés minőségének megítélése nehezen szorítható be objektív mérési paraméterek közé, nem lehet pusztán a célnyelvi produktum minősége alapján standardokat felállítani (Kalina 2005).

A nyelven kívüli tényezők az 1980-as évek végétől jelennek meg a tolmácsolás értékelésében. Pöchhacker (1994) már kontextusban („hypertext”) vizsgálja a minőséget, az ő értelmezésében a kommunikációs interakció sikere a minőségi tolmácsolás elsőszámú ismérve (figyelembe véve az adott konferencia sajátosságait). Daniel Gile (1995/2009) a Basic Concepts and Models for Interpreter and Translator Training című alapmüvében vázolja azt az erőfeszítés-modellt (effort model), amely a tolmácsok teljesítményét, s ezáltal a nyelvi közvetítés minőségét alapvetően meghatározza. Ebben a megközelítésben a tolmács teljesítménye a feldolgozási erőfeszítések (processing efforts) - a megértés, a memória és a beszéd - optimális egyensúlyától függ; ha e három tényező egyensúlya megbomlik, az elkerülhetetlenül minőségromláshoz vezet. Ehhez részben kapcsolódik Kalina (2002) érvrendszere, amelyben a stratégiai feldolgozás (strategic processing) jelenik meg kulcsfogalomként, a minőségromláshoz az ő megközelítésében alapvetően tolmácsolás-stratégiai hibák vezetnek: ahogy nehezedik egy adott szöveg feldolgozása, úgy nő fokozatosan a stratégiai hibák száma, és romlik ezzel párhuzamosan a tolmácsolás minősége (Kalina 2002). Macknél (2002) jelenik meg kiemelten fontos minőség-befolyásoló tényezőként az ekvivalencia megteremtése - tartalmi elemek, formai megvalósítás és előadásmód tekintetében egyaránt $-\mathrm{s}$ ennek megfelelően az ő értékítéletében tolmácsolásnál az elsőszámú cél ugyanazt a hatást elérni, amit a forrásnyelvi beszélő elér a hallgatóságában. Moser-Mercer (1996) szerint a minőség fokmérője - amellett, hogy mennyire pontosan sikerül a beszélő gondolatait átültetni egy másik nyelvre - az, hogy milyen mélységben ismeri a tolmács az adott témát és a szakkifejezéseket. Egy új tényező is megjelenik a minőségbiztosítás szempontjai között, nevezetesen az, hogy a tolmács ismeri és betartja-e a tolmácsokra vonatkozó szakmai etikai szabályokat.

A fenti szerteágazó szempontokat látva joggal merül fel a kérdés, hogy beszélhetünk-e egyáltalán „ideális” tolmácsolási teljesítményről? Annál is inkább, mert - ahogy arra e fejezet bevezetőjében is utaltam -, maga a minőség is erősen szubjektív fogalom a szóbeli nyelvi közvetítés esetében. A felhasználói oldal szempontjai Shlesingernél (1997), Settonnál (1999) és Vuorikoskinál (2004) jelennek meg hangsúlyosabban. Shlesinger szerint három szinten lehet és kell vizsgálni a minőséget: intertextuális, intratextuális és instrumentális szinten, $\mathrm{s}$ az ő rendszerében a tolmácsteljesítmény megítélésekor az általánosan alkalmazható két vezérelv a szöveg hasznossága és érthetősége (Shlesinger 1997). A célnyelvi hallgató segítése Settonnál is kiemelten fontos feladat, szerinte a szóbeli nyelvi közvetítés során - elsősorban a szinkrontolmácsolásnál - a tolmács és a célnyelvi hallgató között müködésbe lép a relevanciaelv: a nyelvi közvetítőnek 
úgy kell segítenie a befogadói oldalt a forrásnyelvi üzenet feldolgozásában, hogy az viszonylag kevés energiát vegyen igénybe (Setton 1999). Vuorikoski (2004) kicsit elrugaszkodik a szigorú értelemben vett tartalmi megfeleltethetőségtől forrásnyelvi és célnyelvi szöveg között, s bevezeti az értelmi konzisztencia fogalmát (sense consistency). Nála a felhasználói szempontok a leghangsúlyosabbak, Mackhez hasonlóan a minőség megítélésekor elsődleges szempontnak tekinti, hogy sikerült-e az eredeti szöveg érvrendszerét és kommunikációs célját átadni. Vourikoskinál (2004) jelenik meg leghangsúlyosabban - éppen az imént vázolt megközelítés miatt, - hogy a tolmácsolás sikeréhez elengedhetetlen a beszélő és a tolmács hatékony együttmüködése. Szinkrontolmácsolási helyzetben Bakti Mária kutatásai is igazolták az együttműködési elv érvényesülésének pozitív hatását a tolmácsolás minőségére (Bakti 2009).

A fentiek alapján kijelenthetjük tehát, hogy a minőség a tolmácsolás esetében nem abszolút fogalom, a tolmács párhuzamosan próbálja meg kiegyenlíteni saját belső erőfeszítéseit (Gile 1995/2009), és egyensúlyt találni a különböző érintett felek céljai és elvárásai között az adott tolmácsolási helyzet keretein belül. Folyamatosan döntéseket kell hoznia, hogy a minőség fenntartása érdekében inkább a szöveghüséget vagy a követhetőséget helyezi előtérbe, inkább a tartalmi vagy a nyelvi pontosságot igyekszik szem elött tartani (Kalina 2005). Ezek persze sok esetben nem egymást kizáró kategóriák, de megvalósításuk és arányaik alapvetően meghatározhatják, hogy mennyiben sikerül megfelelni az adott célcsoport minőségi elvárásainak. A tolmácsolás minősége kétségtelenül sok tényezőn múlik, ezeket összegezve Kalina egy integrált minőségbiztosítási megközelítés alkalmazását javasolja, amely igyekszik valamennyi korábban említett szempontot figyelembe kell venni (Kalina 2005).

A fenti minőségbiztosítási kérdéseket tovább árnyalja, hogy számos olyan külső és belső tényező van, amely növelheti egy adott tolmácsolási helyzet nehézségi szintjét.

\section{A tolmácsolás minőségét befolyásoló tényezők}

A tolmácsolási feladat nehézségét külső és belső körülmények egyaránt befolyásolják. A külső körülmények közé azokat a nyelvi és nyelven kívüli tényezőket sorolom, amelyeken a tolmács nem tud változtatni - a szakirodalom ezeket input változóknak (input variables) hívja (Pöchhacker 2004, Mead 2015). Magára a forrásszövegre vonatkoztatva Gile (1995/2009) probléma-forrásokról (problem triggers), Setton és Dawrant (2016) pedig tolmácsolási csapdákról (interpreting pitfalls) beszél. A belső tényezők közül alapvetően meghatározza a nyelvi közvetítés minőségét a tolmács szakmai kompetenciája, nyelvi és kulturális közvetítési képessége (Kalina 2002, Horváth 2015), valamint az, hogy hogyan képes kezelni az adott tolmácsolási helyzettel járó stresszt. Ez utóbbi külső és belső tényező is egyben, hiszen szubjektív megküzdési stratégiát kíván egy, a külső körülmények összeadódásából származó nehézségre. 


\subsection{A tolmácsolás minőségét befolyásoló külső tényezők (input változók)}

A forrásszövegnek ${ }^{1}$ és az abban megjelenő nyelvi és nyelven kívüli változóknak a tolmácsolás minőségére gyakorolt hatása kedvelt kutatási téma a tolmácsolástudományban, számos kutatás született már a szövegnehézség meghatározására tolmácsolási szempontból. A kutatók egy része - Pöchhacker (2004), Mead (2015), Gile (1995/2009), Setton és Dawrant (2016) - összegezte és egy kidolgozott szempontrendszer szerint csoportosította a lehetséges nehezítő tényezőket, mások - Viaggio (1996), G. Láng (2002), Alexieva (1994), Liu és Chiu (2009) - egy adott szempontot kiemelve vizsgálták annak hatását a tolmácsolás minőségére. Számos megközelítés létezik tehát a szövegek nehézségi szintjének meghatározására, attól függően, hogy a témával foglalkozó kutatók melyik szövegen belüli tényezőt veszik alapul, illetve hogyan csoportosítják ezeket a változókat.

Kétségtelen, hogy minél összetettebb egy előadás témája, minél komolyabb szaktudást igényel egy megbízás, minél nehezebben követhető az adott előadó - akár előadói stílusa, akár jellegzetes beszédmódja miatt, - annál nehezebb fenntartani az elvárt minőséget. Ily módon közvetetten maga az előadó is felelős a tolmácsolás minőségért (Kalina 2005), hiszen ő az, aki szavakba önti, megformázza, felépíti és előadja a feldolgozni kívánt témát. A forrásszöveg minősége, az input tehát nyilvánvalóan hatással van a tolmácsolás minőségére is. Miközben egyetértés van a szakirodalomban a tekintetben, hogy a nyelvi input változók alapvetően meghatározzák a szóbeli nyelvi közvetítés minőségét, a pontos szerepüket és hatásukat igen nehéz kvalitatív elemzési módszerekkel meghatározni, „számszerüsíteni”.

Peter Mead a Routledge Encyclopedia of Interpreting Studies input változókról szóló szócikkében, a tolmácsolás minőségét meghatározó „input” alatt nem csupán a feldolgozandó forrásnyelvi szöveg formai és tartalmi jellemzőit érti, hanem minden olyan külső körülményt, amely befolyásolhatja a tolmácsolás minőségét (Mead 2015). Ebben Pöchhacker (2004) eredeti értelmezésére támaszkodik, aki a tolmácsolási helyzetet meghatározó külső tényezőket összefoglalóan „input változóknak” nevezi: „A figyelem, memória és megértés komplex összjátékát a tolmácsolási folyamatban számos váltakozó „külső” tényező befolyásolja. Ezek elsősorban a forrásnyelvi üzenet milyenségéből adódnak, amely közvetlen „input”-ként szolgál a tolmács mentális feldolgozási műveleteihez." (Pöchhacker 2004: 126, a szerző fordítása)

Pöchhacker három nagyobb csoportba sorolja azokat az input változókat, melyek a forrásnyelvi üzenetet és annak értelmezését alapvetően befolyásolják. $\mathrm{Az}$ első csoportba olyan akusztikus és vizuális, nyelven kívüli változók tartoznak, mint az előadás hangminősége és érthetősége, a beszélő láthatóság. A második csoportba Pöchhacker azokat a változókat sorolja, melyek az előadó sze-

1 Tanulmányomban - részben a szakirodalmi gyakorlatra támaszkodva - a „szöveg” kifejezést a hangzó szövegekre, azaz az elhangzott beszédekre használom. 
mélyével és előadásmódjával vannak összefüggésben, mint például az előadó beszédtempója, akcentusa, intonációja, az előadás folyamatossága, prozódiája, ritmusa. A harmadik nagyobb csoportba tartoznak a forrásszöveg tartalmát és formai megvalósítását érintő nyelvi input változók, ezeket Pöchhacker összefoglalóan a forrásnyelvi szöveg komplexitásának nevezi (source-text complexity). Pöchhacker (2004) ezen belül megkülönböztet (1) textuális, azaz szövegszintü változókat, valamint (2) szintaktikai és (3) lexikai változókat. Az első kategóriába tartozik például a forrásszöveg jellege (elbeszélő vagy leíró), a beszéd információs struktúrája, a szövegen belüli kohéziós elemek. A tolmácsolási folyamat során egyaránt nehézséget okozhat a túlságosan előkészített szöveg - bonyolult mondatszerkesztés, írott nyelvi formulák, magas regiszter, bonyolult szókincs -, és a nem megfelelően előkészített beszéd is, azaz a beszéd felépítésében tapasztalható hiányosságok, következetlenségek, hiszen ilyen esetekben nagyon nehéz az anticipációs technikát alkalmazni. A szintaktikai változók között szerepel a mondatsürűség, valamint az alá- és mellérendelő szerkezetek eloszlása, a szöveg propozíciós struktúrája. A forrásnyelvi szöveg komplexitását meghatározó harmadik nyelvi input változó Pöchhackernél a lexikai sűrűség (Pöchhacker 2004). Egyértelmüen nehézséget okoz a tolmácsoknak, ha a szövegnek nagyon magas az információtartalma, túl sok új információt, adatot akar közölni a hallgatósággal, de ugyanígy problematikus lehet, ha a szöveg nagyon semmitmondó, alacsony a tényleges információtartalma. Különösen a szakmai konferenciáknál jelenthet problémát, ha nagy számban fordulnak elő szakkifejezések a szövegben, az adott témakörre jellemző terminológia ismerete tehát elengedhetetlen a jó tolmácsolási teljesítményhez.

A szövegnehézséget lexikai szempontból vizsgáló kutatásokban olyan szempontok jelennek meg, mint a szógyakoriság, a lexikai variabilitás és a terminológia-használat, a szövegben előforduló számadatok és tulajdonnevek (Gile 1994). Gondot okozhat az is, ha a beszélő eltér az elvárható és feltételezhető megfogalmazásoktól, szokatlan logikai rendszerben, nem hétköznapi szófordulatokkal, vagy a szokásostól eltérő kontextusban használ bizonyos kifejezéseket - az ilyen értelemben vett „kreatív” szóhasználat sok esetben nehezítő tényező lehet (Viaggio 1996). A tolmácsoknak sokszor komoly fejtörést okoz a humoros nyelvi elemek átültetése célnyelvi kontextusba. Kevés tolmácsnak sikerül igazán jól éles helyzetbe, az idő szorításában a humoros szövegrészek lefordítása (Viaggio 1996). A humorhoz hasonlóan az irónia, a szarkazmus és az angolban „understatement”-ként emlegetett eufemisztikus vagy bagatellizáló-jellegü kifejezések fordítása is komoly kihívás egy tolmács számára, hasonlóan a retorikai fogásként alkalmazott szólásokhoz és közmondások, illetve a híres emberektől vagy szépirodalmi művekből származó szó szerinti idézetekhez. Szintén komolyabb háttértudást feltételez a forrásnyelvi közönség számára könnyedén értelmezhető szociokulturális utalások visszaadása (Pöchhacker 2004), esetleges feloldása.

Többen is megkísérelték már osztályozni, graduálni a tolmácsolásra szánt forrásszövegeket nehézségi szempontból. Alexievánál (1999) a szövegek besorolásának egyik legfontosabb paramétere a szemantikai sürüség, az ő értelmezése szerint ez a tényező határozza meg a szöveg „hallgathatóságát” (listenabi- 
lity). Alexieva emellett bevezeti a „jártasság” (familiarity) fogalmát, és a témával kapcsolatos előzetes ismeretek függvényében osztályozza egy-egy tolmácsolási szöveg nehézségét. G. Láng Zsuzsa (2002) táblázatos formában összegzi azokat a paramétereket, melyeknek változtatásával növelhető a forrásnyelvi beszéd nehézsége a tolmácsórákon. A tolmácsolás szempontjából könnyítő, illetve nehezítő tényező lehet ez alapján az üzenet kódolása, az előkészítettség, szóbeliség és specializáció foka, a megközelítés, a beszéd információsűrűsége, szemantikai és nyelvi komplexitása, illetve megjósolhatósága és a téma kulturális meghatározottsága (G. Láng 2002:150). Ahogy fokozatosan nő a forrásszöveg „komplexitása" a felsorolt paraméterek mentén, úgy nehezedik a tolmácsolási feladat.

Liu és Chiu (2009) propozíciós elemzés segítségével igyekezett mérni egy adott tolmácsolási vizsgaszöveg információsűrüségét (information density) és fogalmi sürüségét (concept density), majd az eredményeket összevetették gyakorló tolmácsok és oktatók értékítéletével (kérdőíves kutatás keretében) és a vizsgázók szubjektív benyomásaival, és azt állapították meg, hogy a tudományos mérések eredményei csak részben erősítik meg a gyakorló tolmácsok benyomásait (Liu és Chiu 2009). Daniel Gile (1995/2009) az erőfeszítés-modellből kiindulva foglalta rendszerbe a lehetséges probléma-forrásokat (problem triggers), és négy főbb csoportba sorolta a nehezítő tényezőket. Külön választotta azokat az elemeket, amelyek a megnövekedett feldolgozási kapacitás-igény miatt jelentenek problémát - ide tartozik a gyors előadásmód, a tartalmi szempontból sürü forrásszöveg, az ismeretlen nevek, vagy a nehezen anticipálható tartalmi elemek. A második kategóriába kerülnek azok a nehézségek, melyek a bejövő jel sérülékenységéből erednek (signal vulnerability). Ezekben az esetekben nem maga a feldolgozás jelent nehézséget, hanem a rendelkezésre álló idő rövidsége, illetve a kismértékü redundancia (ilyen „sérülékeny” elemek például a számok vagy rövidítések). A harmadik átfogó kategóriába kerülnek Gile taxonómiájában a nyelv-specifikus problémák, mint pl. az eltérő szintaktikai és nyelvtani szerkezetek, szociolingvisztikai tényezők vagy kultúra-specifikus különbségek. A negyedik lehetséges probléma forrás az előadó személye, előadásmódja (ahogy Gile nevezi, a „speaker factor").

Gile lehetséges probléma forrásait továbbgondolva Setton és Dawrant (2016) részletes listába foglalja a forrásszövegekben „rejtőző” lehetséges tolmácsolási csapdákat (interpreting pitfalls), elsősorban a tolmácsképzés szempontjából releváns gyakorlati szempontok alapján. Settonék öt nagy csoportba sorolják a nehezítő tényezőket: megkülönböztetnek (1) nehezen feldolgozható információs egységeket, (2) nyelvhasználati nehézségeket, (3) pragmatikai jellegü, (4) retorikai és stilisztikai és (5) nyelvspecifikus tolmácsolási csapdákat (Setton és Dawrant 2016: 35-36). A tolmácsolási teljesítmény megítélésekor jól alkalmazható vizsgálati szempont, hogy a tolmácsnak mennyiben sikerült áthidalnia a fenti tolmácsolási csapdákat - tervezett kutatásomban is ez lesz az egyik vizsgált paraméter. Mindezek alapján Setton és Dawrant a tolmácsolási szövegek nehézségi szintjének megállapítására kidolgozott egy ún. beszédnehézségi indexet (Speech Difficulty Index), amely alapján meghatározták, hogy a képzés egyes szakaszaiban milyen jellegü beszédeket érdemes adott célra felhasználni (Setton és Dawrant 2016). A szövegnehézségnek Settonék rendszerében négy fokmérő- 
je van: (1) a téma, (2) az előadás sebessége, (3) szövegsűrüség és stílus, illetve (4) akcentus és prozódia.

Az tolmácsolási helyzet nehézségének meghatározása már korábban is foglalkoztatta Settont (1999). A releváns változók kategorizálásánál az előadáshoz köthető input tényezők (stílus, előadásmód, nyelvi megfogalmazás stb.) és környezeti tényezők (a hallgatóság, technikai felszerelés, visszajelzés módja stb.) mellett egy harmadik kategóriát is megnevez, mégpedig a tolmács személyéből adódó változókat (kompetencia, intelligencia, felkészülés, motiváció) (Setton, 1999). Ez utóbbi tényező, azaz a tolmács személye és felkészültsége Settonnál jelenik meg először ilyen kiemelt hangsúllyal a minőséget befolyásoló tényezők között, a korábbi osztályozások általában inkább az inputtal és annak váltózóival foglalkoztak. Pedig az inputot feldolgozó személy kompetenciái - vagy G. Láng Zsuzsa szavaival (2002:149) „a tolmács felkészültsége, tolmácsolási ismeretei és készségei” szintén alapvetően meghatározzák az adott feladat nehézségi szintjét.

\subsection{A tolmácsolás minőségét befolyásoló belső tényezők (tolmácskompetenciák)}

Sok más hivatáshoz hasonlóan a tolmácsok esetében is gyakran felmerül a kérdés, hogy kiből lesz a jó szakember ezen a pályán: tolmácsnak születni kell vagy bárki képezhető a szakma mesterévé? Vajon milyen képességek szükségesek ahhoz, hogy valaki jó tolmáccsá váljon, és mennyiben fejleszthetők ezek az adottságok? A témának igen kiterjedt szakirodalma van, s jelen tanulmánynak nem célja, hogy mélyrehatóan elemezze a tolmács-kompetenciákat, de a teljesség kedvéért a szóbeli nyelvi közvetítés minőségét befolyásoló belső tényezők között mindenképp érdemes röviden összegezni a tolmácsoláshoz szükséges készségeket.

A Konferenciatolmácsok Nemzetközi Szervezete (AIIC) 1993-ban fogalmazta meg útmutatásait a konferenciatolmácsoktól elvárt ismereteket és adottságokat illetően. Az elvárt ismeretek között szerepel többek között, hogy az illető tökéletesen birtokolja az aktív nyelv(ek)et; behatóan ismerje a passzív nyelv(ek)et; felsőfokú végzettséggel (vagy ennek megfelelő képesítéssel) rendelkezzen és tájékozott legyen az aktuális eseményeket illetően. A tolmácsok számára elengedhetetlen adottság az adatok elemzésére és értelmezésére való készség, intuíció, gyors reakcióidő és a különböző előadókhoz, helyzetekhez és témákhoz való gyors alkalmazkodás képessége; fontos a jó koncentrációs képesség, az átlagosnál jobb fizikai és idegi állóképesség; kimagaslóan jó memória; kellemes hang és jó előadói tulajdonságok. (AIIC 1994, idézi: Horváth, Szabari és Volford 2000: 177-178)

A tolmács-kompetenciák összegzése nem csak a gyakorló tolmácsok számára jelenthet megerősítést, nem pusztán egy jegyzék a tolmács „életpálya-modell” kiépítéséhez szükséges eszköztárról - a jövő tolmácsainak is útmutatásul szolgál a pályaorientációhoz. Kalina (2000) kifejezetten tolmácshallgatók számára összegzi a tolmácsoláshoz szükséges legfontosabb kompetenciákat, és azok fejleszthetőségét vizsgálja. A tolmácsképzésben kiemelten fontos szempont, hogy a tolmács tisztában legyen kommunikációs közvetítői felelősségé- 
vel, ismernie kell a tárgyaló felek között fennálló kulturális, politikai, gazdasági, szociális és etnikai különbségeket. Emellett képesnek kell lennie megfelelni az adott kommunikációs helyzetben elvárt stiláris, regiszterbeli és kulturális normáknak. Kalina definíciója szerint a tolmács-kompetencia azt jelenti, hogy az illető „képes egy adott két-, vagy többnyelvű kommunikációs helyzetben magas szintű minőségi elvárásoknak megfelelően ellátni a nyelvi közvetítés kognitív feladatát" (Kalina 2000: 2, szerző fordítása).

A tolmács-alkalmassági vizsgákat áttekintve Moser-Mercer (1994) az alábbi tesztelési paramétereket gyüjti össze: a jelölt anyanyelvi és idegen nyelvi ismeretei, általános műveltsége, beszédértési (analizáló és szintetizáló) képességei, a beszédprodukció gyorsasága, beszédhang és dikció, memóriakapacitás, egyidejü beszédhallgatás és -produkció képessége; stressztürő képesség, állóképesség. Az alkalmassági vizsgákra vonatkozóan Alexieva is fogalmaz meg ajánlásokat (1994), szerinte azt kell elsősorban vizsgálni, hogy a jelöltek mennyire képesek összekapcsolni az elsajátított ismereteket, felismerik-e az összefüggéseket, illetve képesek-e kontextusban is felhasználni a megszerzett tudást. Olyan alkalmassági vizsgafeladatokat javasol, melyek egymásra épülve tesztelik a jelöltek információfeldolgozási képességeit (Alexieva 1994).

G. Láng Zsuzsa a felsőfokú tolmácsképzésről szóló könyvében (2002) külön fejezetet szentel annak, hogy ki és milyen feltételek mellett képezhetö tolmáccsá. Három szempontot vizsgál a tolmácsjelöltek alkalmasságának megítélésekor: (1) munkanyelvek megfelelő ismerete; (2) kognitív képességek (elemzés, szintetizálás, problémamegoldás); (3) kiváló kommunikációs készség (G. Láng 2002: 66). Ez utóbbit, azaz a kommunikatív kompetenciát Horváth Ildikó is kiemelten fontosnak tartja a tolmácsok munkájában, egész pontosan „a nyelvi jelek kontextusban történő kódolására és dekódolására való képességet egy multidimenzionális kommunikációs helyzetben" (Horváth 2015: 28). A tudatos kommunikációnak Horváth szerint a tolmácsok verbális és nonverbális kommunikációjában egyaránt meg kell jelennie, „ismerniük kell kommunikációjuk egyéni jellemzőit a nyelvtudásuktól és beszédkészségeiktől kezdve a hangképzési sajátosságaikon át (beszédük hangszíne, hangmagassága, ritmusa) a testbeszédükig" (Horváth 2015: 34). Horváth rámutat arra, hogy a fordítókra és tolmácsokra a szakirodalomban egyre inkább kultúraközi közvetítőként tekintenek, és ez az interkulturális kommunikátori szerep megkíván bizonyos mértékü kulturális kompetenciát is.

A szakirodalom és gyakorlatai tapasztalatok alapján leszögezhetjük, hogy a tolmács-jelöltek alkalmasságának felmérésekor számos szempontot figyelembe kell venni, melyek gyakran túlmutatnak a magas szintủ nyelvtudáson, illetve a megszerzett kompetenciákon. A pszicholingvisztika szempontjait is bevonva, egyre nagyobb hangsúlyt kap - az alkalmassági vizsgákon és a tolmácsképzésben egyaránt - bizonyos kognitív készségek fejlesztése. Válóczi (2010) e készségek közé sorolja többek között az analizáló és szintetizáló képességet, memóriát, kreativitást, koncentrációs készséget, valamint a szimultaneitást. Úgy véli, számos személyiségjegy (önismeret, empátia, intuíció, érzelmi intelligencia, önbizalom, stb.) összjátéka szükséges a tolmács kompetencia kialakulásához (Válóczi 2010). A kognitív készségek, illetve személyiségjegyek közül meghatá- 
rozó jelentőségű a tolmácsok munkájában - akár úgy is fogalmazhatnánk, sok esetben ezen áll vagy bukik egy tolmács hosszú távú sikeressége a szakmában -, hogy hogyan képes kezelni a folyamatos megmérettetéssel járó stresszt.

\subsection{A stresszfaktor hatása a tolmácsolási feladat nehézségére}

A tolmácsoláskutatásban már régóta kedvelt téma a stressz, ami valószínűleg annak tudható be, hogy ilyen kiszámíthatatlan mértékủ és jellegü kognitív megterheléssel aránylag kevés munkakörben kell megküzdeni. A szakirodalmi definíciókból mára már közismert meghatározás alapján a stressz általában „valamilyen vélt vagy valós veszély vagy fenyegetés eredménye, olyankor jelentkezik, amikor úgy érezzük, képtelenek vagyunk megbirkózni az adott szituációval" (Horváth 2015: 122). Ha Gile (1995/2009) erőfeszítés-modelljére vonatkoztatjuk ezt az alapvetést, akkor azt is mondhatjuk, hogy a stressz a meglévőkön felül egy újabb erőfeszítést kíván a tolmács részéről, további energiát von el a feldolgozási kapacitástól, ezáltal szükségszerüen rontva a nyelvi közvetítési teljesítményen. A képlet azonban nem ilyen egyszerü: a stressz hatása valóban sok esetben megmutatkozik a szóbeli nyelvi közvetítés minőségén - gyakran negatív értelemben, de időnként pozitív előjellel.

A szakemberek sokáig egyértelmúen negatívumként tekintettek a stresszre, megítélése csak az 1970-es végén kezdett megváltozni, ami elsősorban Selye (1976) munkásságának köszönhető. Ő volt az, aki rámutatott, hogy a stressz nem feltétlenül káros (ún. distressz), megfelelő stresszkezelési módszerek alkalmazásával akár előnyünkre is fordíthatjuk. Selye (1976), majd a későbbiekben Zeier (1997) kutatásai a stresszt kiváltó fiziológiai és pszichológiai tényezőket vizsgálták, és összegyüjtötték azokat a biokémiai reakciókat, amelyeket egy-egy stresszhelyzetben az emberi szervezet adhat. A stressz müködési mechanizmusának, tüneteinek ismerete és a stresszre adott fiziológiai reakciók felmérése, az ún. stresszfelismerés (stress literacy) (Smith 1993) mindenképpen szükséges ahhoz, hogy kifejleszthessük saját személyre szabott stresszkezelési módszereinket. Zeier (1997) arra a megállapításra jutott, hogy a stresszre adott reakciók egy része aktív megküzdési stratégiákat tükröz, másik része inkább passzív elkerülő magatartásra utal.

Cooper és munkatársai 1980-ban végeztek először átfogó felmérést konferenciatolmácsok körében a szinkrontolmácsolással járó stressz-terhelés felmérésére (Cooper et al. 1982). A megkérdezett tolmácsok válaszai alapján négy kategóriába sorolhatók a szakma-specifikus stressztényezők. Stresszfaktorként jelennek meg a tolmácsok számára (1) bizonyos fizikai környezeti tényezők (tolmácskabin mérete, szellőzése, világítása, a hangosítás minősége, háttérzajok szürése stb.); (2) a munka és a magánélet összeegyeztetésének nehézségei; (3) az interperszonális kapcsolatok egyensúlyban tartása (kollégákkal, megbízókkal, feljebbvalókkal); és (4) a konkrét tolmácsolási feladatból adódó nehézségek (a beszélő hiányos előadói képességei, felkészülési és szervezési nehézségek, viszszajelzés hiánya stb.).

Részben Cooper és munkatársai eredményeiből kiindulva készült el a Konferenciatolmácsok Nemzetközi Egyesületének (AIIC) megbízásából a 2002-es 
Workload Study. Mint a neve is mutatja, ez a felmérés a konferenciatolmácsok munkahelyi stressz-terhelését vizsgálja, elsődleges célkitűzése az volt, hogy alátámassza az AIIC iránymutatásait a konferenciatolmácsok munkakörülményeire vonatkozóan. A vizsgálat azokat a tényezőket vette számba irányított szempontok alapján, amelyek megnehezíthetik a munkavégzést a nemzetközi intézmények tolmácsai számára. A felmérés során alkalmazott vizsgálati szempontok a következők voltak: pszichológiai tényezők (attitűd, elégedettség, motiváció stb.); munkakörnyezet (hangszigetelés, szellőzés, világítás a kabinokban); a tolmácsok fiziológiai jellemzői (vérnyomás, pulzus stb.) és interperszonális tényezők (AIIC Workload Study 2002). Az eredmények alapján számos következtetést vonhatunk le a tolmácsok stressz-terhelésére vonatkozóan - ahogy arra Horváth (2015) is rámutat, - többek között azt, hogy a fiziológiai tényezők vizsgálatával hatékonyan mérhető, hogy az adott helyzetben mennyire stresszes a tolmács. Más elemzőkhöz hasonlóan Horváth is úgy látja, hogy a Workload Study talán „legfőbb érdeme, hogy részletesen elemzi, a fizikai munkakörnyezet hatásai miként vezethetnek stresszhez és kiégéshez" konferenciatolmácsoknál (Horváth 2015: 121). Érdemes megemlíteni, hogy a felmérés szerint a forrásnyelvi szöveg minősége, azon beül is az előadásmód, az előadó személye, a beszéd felolvasottsága stb., mind növelik az adott tolmácsolási helyzetben a stressz érzésének kialakulását, $\mathrm{s}$ ezzel közvetetten hatással vannak a tolmácsolás minőségére is. A felmérés eredményeiről és tanulságairól részletesen olvashatunk Moser-Mercernél (1996) és Horváthnál (2015). Az AIIC felmérése elsősorban a szinkrontolmácsolásra vonatkozott, de az eredményeket más tolmácsolási módokra is lehet adaptálni.

A Workload Study értékelő rendszerében a stressztényezők lehetséges negatív hatásai álltak a középpontban, de azért az is kiderült, - és ezt Boronkay-Roe 2006-os felmérése is alátámasztja - hogy a stressz kezelése alapvetően alkati kérdés. Aki erre a pályára lép, tisztában van a munkával járó megnövekedett stresszel, és vélhetőleg kellő önbizalommal rendelkezik ahhoz, hogy tudatosan ellensúlyozza a stresszorok okozta plusz megterhelést. Még az is előfordulhat, hogy kifejezetten a stresszkereső embertípusba tartozik. (Horváth 2017). Boronkay-Roe (2006) 66 tapasztalt tolmácsnál vizsgálta a streszsz és a tolmácsolás összefüggéseit. Egyértelműen kimutatható volt, hogy a válaszadók stresszesnek találják a tolmácsolást, ám az is kiderült, hogy túlnyomó többségük - elsősorban olyanok, akik részt vettek valamilyen képzésen - tudatosan alkalmaz valamilyen aktív megküzdési stratégiát a stresszfaktor ellensúlyozása érdekében (pl. koncentrációt segítő mentális technikákat). Bíztató eredmény, hogy a megkérdezettek többsége úgy nyilatkozott, hogy a munkája során tapasztalt stressz szintje az idő múlásával fokozatosan csökken, ami arra utal, hogy a tolmács kompetenciák erősödésével hatékonyabban ellensúlyozható a stresszorok hatása. (Az AIIC felmérése is hasonló végkövetkeztetésre jutott.)

Mouzourakis (1996) kutatásai is azt mutatták, hogy stresszes helyzetben a tolmácsok jelentős része alkalmaz - többé-kevésbé tudatosan - valamilyen védekezési mechanizmust. Az ő értelmezésében létezik egyfajta „stressz homeosztázis, amikor is a tolmácsok a lehetetlennek tűnő munkakörülményekre reagálva fokozatosan csökkentik az erőfeszítéseiket" (Mouzourakis 1996, idézi 
Horváth 2015:123). Ez kicsit emlékeztet Gile szaturációs elméletére (Gile 1995/2009), mely szerint egy ponton túl a tolmács telítődik a rá nehezedő párhuzamos feladatok súlyával, és nem tud további energiákat átcsoportosítani tehát szükségszerüen romlik a teljesítménye.

A stressz mértékét igen nehéz számszerüsíteni, de a stresszorokra adott fiziológiai reakciókat többen is vizsgálták kvantitatív megközelítésben. Klonowicz (1994) kutatása például megnövekedett diasztolés és szisztolés vérnyomást és gyorsabb szívverést mutatott ki a tolmácsolási helyzet elején, amit „mobilizációs hullámnak" nevezett el (Klonowicz 1994). Moser-Mercer kimutatta, hogy az elnyújtott váltások, azaz a szokásosnál hosszabb tolmácsolási periódusok növelik a tolmácsok stressz-szintjét (ezt a kortizol-koncentráció segítségével mérték), és ezáltal hatással vannak a tolmácsolás minőségére (Moser-Mercer 1996). Moser-Mercerhez hasonlóan Kurz (2002) is igyekezett feltérképezni a stressz fiziológiai megnyilvánulásait különböző tolmácsolási helyzetekben, Kurz például a médiatolmácsolás jelentette extra stressz mérésére a bőr vezetőképességét (az ún. galvanikus bőrreakciót) és a pulzusszámot vizsgálta, és sikerült kimutatnia - ugyan aránylag kis mintából -, hogy a média-tolmácsolás megnövekedett stressz-terhelést jelenthet (Kurz 2002).

A stressz és szorongás mértékének mérésére a saját bevalláson alapuló stressz- és szorongás-felmérések is érdekes eredményeket hoztak (tulajdonképpen Cooper és társai is ilyen módszerrel gyújtötték adataikat). Pavel Korpal kutatása (2016) például saját bevalláson alapuló interjúkon keresztül vizsgálta hallgatók körében a tolmácsolás során jelentkező stressztényezőket, a konszekutív és szinkrontolmácsolás között e tekintetben tapasztalható különbségeket és a megkérdezett tolmácsok megküzdési stratégiáit (Korpal 2016). Érdekes tanulságokkal szolgáltak az interjúk, kiderült ugyanis, hogy a tolmácshallgatók többsége a konszekutív tolmácsolási helyzetet érezte stresszesebbnek, hiszen itt külön stresszorként jelentkezett, hogy közönség előtt kellett beszélni. A szinkrontolmácsolásnál nagyobb biztonságban érezték magukat a kabin izoláltságában. További gyakran megjelölt stressztényező volt a hibázástól való félelem és a tolmácsolás során a munkakörülményekben felmerülő technikai nehézségek (pl. nem látták, hallották jól az előadót) (Korpal 2016: 309-310).

A vizsgastressz, vagy - szakkifejezéssel élve - a teljesítményszorongás kutatása, azon belül is kifejezetten a szorongás kognitív folyamatokra gyakorolt hatásának vizsgálata több évtizedes múltra tekint vissza a pszichológiában. Sarason és munkatársai az 1950-es években a szorongás és a teljesítmény között fennálló kapcsolatokat próbálták beazonosítani, és - sok későbbi kutatáshoz hasonlóan arra az eredményre jutottak, hogy jelentős egyéni eltérések vannak a stresszhelyzetre adott viselkedéses válaszokban (Sarason 1950). Nyilván meghatározó lehet e tekintetben, hogy az adott személy inkább sikerorientált vagy kudarckerülő típus (Atkinson 1957). Ennek megfelelően a teljesítményhelyzetben adott reakció alapján beszélhetünk debilizáló és facilitáló szorongásról. Miközben a debilizáló szorongás ronthatja a teljesítményt, a facilitáló szorongás pozitív hatással lehet rá - legyen szó tanulási folyamatról, sportversenyekről vagy tolmácsolási helyzetről (Horváth 2017). Csíkszentmihályi (2008) úgy véli, ha a tanuláshoz pozitív képzetek társulnak, és a tanuló fejében összekapcsolódik a megelégedett- 
ség és az öröm érzésével, akár egy szorongásmentes, ideális állapot (flow) is létrejöhet. A Yerkes-Dodson törvény szerint akkor tudunk optimálisan teljesíteni, ha a kihívás mértéke és az aktivitási szint nagyjából közepes értékü, ennek megfelelően sem a túl magas, sem a túl alacsony stressz szint nem segít abban, hogy kihozzuk magunkból a maximumot (N. Kollár és Szabó 2004).

Mindezek alapján, ha a tolmácsvizsgák szempontjából közelítjük meg a fent részletezett tényezőket, összegezve azt mondhatjuk, tolmácsolási vizsgahelyzetben a vizsgáztató felel a külső tényezőkért, a tolmácshallgatónak kell kezelnie a belső tényezőket. Vizsgáztatóként a külső változókat kell irányítanunk: a nyelven kívüli külső tényezőket (a vizsgakörülményeket) uniformizálni, a nyelvi külső tényezőket (a vizsgaszövegeket) pedig optimalizálni kell annak érdekében, hogy reálisan ítélhessük meg egy hallgató teljesítményét vizsgahelyzetben. A vizsgázóknak ezzel szemben a belső tényezőket kell tudatosan irányítaniuk, hiszen arról kell számot adniuk, hogy mennyiben sikerült elsajátítaniuk a hatványozottan stresszes tolmácsolási helyzet megoldásához szükséges tolmács-kompetenciákat és stressz-kezelési módszereket. Minél sikeresebben valósul meg ez a két - vizsgáztatói, illetve hallgatói - célkitűzés, annál nagyobb eséllyel teljesítenek jól a vizsgán a tolmácshallgatók.

\section{A tolmácsolás minőségének mérése, értékelése a tolmácsvizsgákon}

Korábban megállapítottuk, hogy a számos változó miatt rendkívül nehéz objektív eszközökkel mérni a tolmácsolás minőségét - a teljesítmény minőségének megítélése csak adott helyzetben, adott körülmények között lehet érvényes, nincsenek általános érvényủ minősítési kritériumok.

A tolmácsképző intézményeknek valahogy mégis értékelniük kell hallgatóik teljesítményét - lehetőség szerint objektív, többekre egységesen alkalmazható kritériumrendszerben. Ez első lépésben a tolmácsjelöltek alkalmasságának tesztelését jelenti a felvételi vizsgákon. Ezeken a vizsgákon általában a kognitív-elemző és a kommunikációs kompetenciák állnak a vizsgálatok középpontjában. A trieste-i egyetemen az 1990-es évek közepén a résztvevő hallgatók bemeneti és kimeneti teljesítményének összevetésével igyekezték igazolni azt, hogy már a felvételi vizsga alapján következtetni lehet a jelentkező várható „előmenetelére" (G. Láng 2002). Ahogy az előző fejezetben láthattuk, a kutatásokban újabb és újabb kompetenciák kerülnek az érdeklődés középpontjába, melyek a tolmácsjelöltek alkalmasságát segíthetnek megítélni a bemeneti vizsgákon. Az egyéni intelligencia és enciklopédikus ismeretek mellett Darónál (1994) a figyelem-megosztási képesség, a rövid távú memória és a folyamatos beszédre való képesség is megjelenik. Alexieva (1993) elsősorban azt vizsgálná az alkalmassági vizsgán, hogy a jelölt hogyan és milyen mértékben képes felhasználni a korábban szerzett ismereteket, ezért konkrét javaslatokat fogalmaz meg egy kétlépcsős felvételi vizsgafeladat-sorra, mely elsősorban az információfeldolgozás hatékonyságát vizsgálja. Moser-Mercer (1994) szerint mindenekelőtt a képzés célját, időtartamát, súlypontjait kell szem előtt tartani a jelöltek alkalmassá- 
gát vizsgáló tesztekben. Az anyanyelvi és idegen nyelvi ismeretek mellett fontos vizsgálni a jelöltek kognitív készségeit, személyiségjegyeit, tanulási görbéit is.

A magyar és külföldi tolmácsképző intézmények igyekeznek a fenti szempontokat figyelembe véve kialakítani felvételi vizsgáikat, a konkrét feladatok skálája ugyanakkor igen széles. A tapasztalatok azt mutatják, hogy időről időre érdemes felülbírálni és megújítani a piaci (és részben hallgatói) elvárások fényében a vizsgakövetelményeket, illetve a vizsga felépítését. A konferenciatolmács képzésben útmutatóul szolgálhatnak a European Masters in Conference Interpreting (EMCI) program standardjai és az Európai Bizottság tolmácsszolgálatának (SCIC) ajánlásai.

A folyamatos megújulás és alkalmazkodás igénye megjelenik a kimeneti képesítő vizsgák esetében is. Itt az értékelési rendszer kidolgozásánál együttesen kell figyelembe venni a piaci elvárásokat, a minőségbiztosítási alapelveket, illetve azt, hogy reálisan milyen teljesítmény várható el a hallgatóktól a képzési struktúra alapján. G. Láng Zsuzsa (2002) szerint a tolmácsolás megítélésénél az elsődleges szempont az, hogy ,átment-e az üzenet”, ami a szemantikai tartalomból és a beszélő szándékából tevődik össze (G. Láng 2002: 158). G. Láng külön is megjelöl olyan értékelési szempontokat, melyek kifejezetten csak az egyik tolmácsolási módnál érvényesek, és két külön értékelőlapot mutat be a konszekutív- (2002: 162) és a szinkrontolmácsolási teljesítmény értékelésére (2002: 186). Az arányok hasonlóak a vizsgált paraméterek mentén: a tartalmi tényezők $40 \%$-ban számítanak be az összesített eredménybe, a nyelvi megvalósítás (tehát formai szempontok) 30\%-ban, az elsajátított tolmácsolási technikák szintén 30\%-ban. A konszekutív tolmácsolás értékelésében hangsúlyosabban jelenik meg a gondolati egységek közötti összefüggések felismerése, a prezentáció, az adatok, nevek, részletek pontosságának ellenőrzése megfelelő jegyzetelési technikával. Szinkrontolmácsolásnál a kimenő hang kontrollálása, a tudatos hangképzés, általában az önmonitorozás, a mondatok befejezettsége is szerepel az értékelési szempontok között. Mindkét esetben megjelenik az értékelőlap alján, hogy milyen összbenyomást tett a hallgató az értékelőre, ami egy fontos elvi kérdésre világít rá.

Gyakran felmerül a tolmácsoláskutatásban, hogy holisztikus vagy analitikus megközelítésben célszerü-e értékelni a tolmácshallgatók teljesítményét. Az oktatók és a témát vizsgáló kutatók nagy része inkább a holisztikus értékelést támogatják, melyet optimális esetben az analitikus módszerekkel nyert eredmények is alátámasztanak. Az órai értékelés általában diagnosztikus jellegü, a reális önértékelést segíti, de a képzést lezáró képesítővizsga már egyfajta „abszolút mércét állít" (G. Láng 2002), melynek elérését nagymértékben befolyásolhatja a vizsgahelyzetből adódó stressz. Ennek megfelelően a tolmácshallgatók teljesítményének értékelésében alapvetően két megközelítés bontakozott ki az elmúlt évtizedekben. Az első, nyelvészeti jellegű analitikus megközelítés a tolmácsolás során tapasztalható hibákat kategorizálja, számszerúsíti és elemzi (annak érdekében, hogy hosszú távon tudatosítsa és minimalizálja ezeket a hibákat). A második, didaktikai jellegü, holisztikus megközelítés a tolmácsteljesítmény egyes szegmenseit vizsgáló értékelési sémákkal dolgozik, és értékelőlapokon keresztül ítéli meg a nyelvi közvetítés minőségét. 
Az első, nyelvészeti megközelítést alkalmazó kutatók többnyire Barik (1975) hibatipológiájából indulnak ki. A legfontosabb hibatípusok Bariknál a következők: kihagyás, hozzáadás, helyettesítés, szószerinti fordítás, téves szóválasztás, nyelvtani és szintaktikai hibák; torzítás; regiszter-tévesztés (Barik 1975). Barik részletesen kidolgozott hibatipológiája valóban segíthet az oktatóknak bekategorizálni a tolmácsolási hibákat, a hallgatókban tudatosítani a lehetséges hibaforrásokat, és - nem utolsósorban - igen jól használható eszköz a tolmácsoláskutatók számára a tolmácsolási teljesítmény értékelésére. Altman (1994) is Barik hibatipológiájára alapozza értékelési rendszerét, melyben a konferenciatolmács-hallgatók szinkrontolmácsolási teljesítményének értékelésére négy nagyobb hibacsoportot állított fel: (1) kihagyás, (2) hozzáadás, (3) egyes lexikai elemek pontatlan tolmácsolása, (4) hosszabb kifejezések pontatlan tolmácsolása. Bariktól eltérően Altman a nyelvi hibákon túlmenően a tolmácsolás kommunikatív aspektusára is kiterjesztette a hibakategóriáit, és a fenti hibacsoportokat annak fényében vizsgálta, hogy mennyiben gátolták a kommunikációs cél megvalósulását (Altman 1994:26).

A tolmácsteljesítmény értékelésének holisztikus megközelítésénél a tolmácsolási hibák kategorizálásának csak másodlagos jelentősége van, az értékelés központjában az előzetesen lefektetett minőségbiztosítási kritériumok teljesítése áll. E megközelítést alkalmazva, az 1990-es évektől kezdve számos tolmácsoláskutató dolgozott ki értékelőlapokat tolmácsolási események elemzésére és azon belül a hallgatók teljesítményének értékelésére (Schjoldager 1996, Gillies 2004, Kutz 2005, Kalina 2002). Ezeken az értékelőlapokon a szerzők egyértelmüen lefektetik az értékelésnél figyelembe vett szempontokat. Jelen tanulmány behatárolt keretein túlmutat valamennyi értékelési módszer részletes bemutatása, de néhányat közülük érdemes röviden felvázolni.

Schjoldager (1996) dolgozott ki elsőként a szinkrontolmácsolási teljesítmény minőségének megítélésére egy értékelő sémát, amelyben négy főbb értékelési kritériumot jelöl meg a tolmácshallgatók teljesítményének értékeléséhez: (1) érthetőség és előadásmód, (2) nyelvhasználat, (3) koherencia és (4) hüség. Schjoldager a főbb szempontok alá eldöntendő kérdéseket rendel, ezek megválaszolásával születik meg a végső értékelés. A módszer előnye, hogy nem megy bele aprólékos elemezgetésbe, s maguk a tolmácshallgatók is használhatják a képzés aránylag korai szakaszától önértékelésre - annál is inkább, mert az egyes kritériumoknál rövid leírás is olvasható arról, hogy miért fontos az adott szempont. Ugyanakkor néhány összetettebb kérdés túlzottan is leegyszerüsödik, s a kérdőív nem mindig ad teret árnyaltabb válaszokra. Ezzel szemben Kutz (2005) értékelőlapja igen aprólékosan kidolgozott makro- és mikrokritériumokat is felsorakoztat szinkrontolmácsolási gyakorlatokhoz, és részletes magyarázattal szolgál minden egyes értékelési szemponthoz. Oktatói szemmel mindenképpen hasznos a részletekbe menő elemzési keret - bár kétségtelenül igen időigényes a kitöltése -, ugyanakkor hallgatói önértékelésre nem igazán alkalmas. Jellegében leginkább Kalina korábban hivatkozott minőségellenőrzési adatlapjához hasonlítható (Kalina 2005), mely szintén igen részletes (a valós tolmácsolási helyzetekből indul ki, kitér a felkészülésre, sőt, még a szerződéskötés körülményeire is), de hallgatói szemmel nem túl „felhasználóbarát”. A hall- 
gatói önértékelés jelentőségére már Gillies (2004) is rámutatott, azt javasolta a tolmácshallgatóknak, hogy hallgassák vissza magukat, s olyan tolmácsolási teljesítményre törekedjenek, melyet akár anyanyelvi beszélők is nyújthattak volna. Nála felmerül annak a lehetősége is, hogy a hallgatók saját tolmácsolási teljesítményüket utólag, a célnyelvi produktum leirata alapján elemezzék részletekbe menően (Gillies 2004).

A legtöbb tolmácsképző intézmény jelenleg alkalmazott értékelési rendszerében három fó szempont jelenik meg - tartalmi pontosság, célnyelvi minőség, előadásmód. Ez a hármas szempontrendszer köszön vissza - némileg átdolgozott formában - a European Masters in Conference Interpreting (EMCI) értékelésre vonatkozó ajánlásaiban, valamint Setton és Dawrant konferenciatolmács-képzési „útmutatójában” is (2016). Az EMCI hálózathoz tartozó tolmácsképző intézményekben az értékelésnél egységes kritériumrendszert alkalmaznak. 2013-as tanulmányában Jantsits Ágnes is összefoglalja a vizsgálati szempontokat: (1) az A nyelv tökéletes ismerete - szókincs, regiszter-váltások, interferencia-kerülés stb.; (2) megértés - megérti a munkanyelvein elhangzó beszédeket, célnyelvi előadása koherens, érti és használni tudja az adott tárgykörhöz tartozó szakkifejezéseket mindkét nyelven; (3) feladattudatosság - folyamatosság, pontosság, problémamegoldási képesség, jó prezentáció, stresszkezelés, tolmácsolási technikák alkalmazása (Jantsits 2013: 172).

Setton és Dawrant (2016) is hármas szempontrendszert alkalmaz a vizsgafeladatok értékelésére, ezek a tartalmi szöveghüség (fidelity of content); a kifejezésmód, nyelvhasználat pontossága és választékossága (expression); valamint az előadásmód gördülékenysége (delivery). Settonék is megfogalmaznak az egyes tolmácsolási feladatokra érvényes további kritériumokat, konszekutív tolmácsolásnál megjelenik például az időkontroll, a hangerő/hanghordozás kérdése, a szemkontaktus tartása és a viselkedés, illetve fellépés kérdése is. A szinkrontolmácsolási teljesítmény értékelésénél olyan szempontokat is figyelembe kell venni, mint a kabin-etikett betartása, a technikai felszerelés hatékony használata és az optimális fül-száj ívhossz tartása (Setton és Dawrant 2016).

\section{További kutatási irányok}

Az elmúlt évtizedek fent bemutatott kutatásaira alapozva számos további kutatási irány körvonalazódik, hiszen a témának egyaránt vannak lexikai, szövegnyelvészeti, pszicholingvisztikai és oktatásmódszertani vonatkozásai is. Ezek a kutatások több szempontból is hasznosnak bizonyulhatnak a tolmácsoláskutatás, és különösen a tolmácsképzés számára.

Jó kiindulópont lehet a további kutatásokhoz a jelenlegi magyarországi és nemzetközi tolmácsvizsgáztatási gyakorlat, valamint a tolmácsvizsgákon alkalmazott értékelési módszerek felmérése és összegzése. Különösen igaz ez a tolmácsképző intézmények záróvizsgáira, azok felépítésére és vizsgaszövegeire, valamint a vizsgán nyújtott tolmácsolási teljesítmény megítélésénél használt értékelési szempontokra. Az egyes intézmények vizsgáztatási módszereinek áttekintése, a jó gyakorlatok összegyújtése kölcsönösen előnyös lehet a tolmácsképzők számára. 
Szintén előremutató lenne a tolmácshallgatók vizsgateljesítményét befolyásoló nyelvi és nyelven kívüli tényezők rendszerbe foglalása - a vonatkozó szakirodalomból kiindulva, ugyanakkor a tolmács-oktatók és -hallgatók gyakorlati tapasztalatait és az optimális vizsgakörülményekkel szemben támasztott elvárásait is figyelembe véve. Külön érdemes megvizsgálni, hogy hogyan építhető be még tudatosabban a stressz-kezelés, mint a szóbeli nyelvi közvetítés minőségét alapvetően befolyásoló külső és belső tényező a képzési programokba.

A tolmácsolt beszédek nehézségi fokát meghatározó szempontok ismételt összegzése, illetve az „optimális” tolmácsvizsga-beszédek kritériumainak rögzítése a meglévő standardok - elsősorban a European Masters in Conference Interpreting (EMCI) program ajánlásai -, és az Európai Bizottság Tolmácsolási Szolgálatának (SCIC) beszédgyüjteményénél (Speech Repository) alkalmazott szövegnehézség-besorolási szempontok alapján, segíthet a tolmácsképző intézmények oktatóinak abban, hogy hatékony graduálási és vizsgafelkészítési rendszert dolgozzanak ki a képzés során.

Értékes tanulságokkal szolgálhat - az oktatók és a hallgatók számára egyaránt - a nyelvi közvetítés minőségének vizsgálata és összehasonlító elemzése órai vizsgaszimulációs gyakorlatokon és éles vizsgahelyzetben, azaz olyan párhuzamos tolmácsolási helyzetekben, melyek a szövegnehézség szempontjából és a feladat jellegét tekintve hasonló paraméterekkel rendelkeznek, de eltérő megterheléssel járnak a tolmács számára a megnövekedett stressz-tényező miatt. Ahogy arra G. Láng Zsuzsa is rámutat, tolmácsvizsgákon „a végső értékelést nehezíti a nagyfokú stressz, ami a feladat természetéből és a vizsgabizottság előtti szereplésből fakad, és jelentősen leronthatja a teljesítményt" (G. Láng 2002: 185). A szimulált (azaz kevésbé stresszes) és az éles (tehát stresszel „terhelt”), vizsgán nyújtott teljesítmények között mutatkozó tendenciózus eltérések elemzése és tudatosítása segíthet abban, hogy a hallgatók a megfelelő áthidalási stratégiákat tudják alkalmazni a vizsgahelyzetben. További kutatás tárgyát képezheti, hogy kimutatható-e szignifikáns különbség az egyes tolmácsolási módok között a stressz-tényező hatását és a stresszkezelési mechanizmusok hatékonyságát illetően - hiszen maguk a szakemberek is megosztottak a tekintetben, hogy vajon a konszekutív- vagy a szinkrontolmácsolási feladatoknál nagyobb a stressz-terhelés.

Összegezve azt mondhatjuk, hogy az optimális vizsgakörülmények és az ideális nehézségü vizsgabeszédek kritériumainak rögzítése hallgatói és oktatói szempontból is örvendetes perspektíva, és kétségtelenül hozzájárulhat a vizsgakészülés hatékonyságának növeléséhez. A vizsgateljesítmény értékeléséhez gyakorlatban is jól alkalmazható szempontokat adhat további tartalmi és formai minőségelemzési módszerek kidolgozása. Végül, de nem utolsósorban jelentősen javíthatja a szóbeli nyelvi közvetítés minőségét a tolmácsvizsgákon, ha a hallgatók és az oktatók tisztában vannak a vizsga jelentette stressz hatásaival, hiszen így célirányosan, a gyakrabban előforduló hibatípusokra fókuszálva alakíthatnak ki megküzdési stratégiákat a stressz kezelésére. Hosszú távon tehát minden ezirányú kutatás hozzájárulhat ahhoz, hogy a hallgatók a stressztényező lehetséges hatásainak tudatában - jobban teljesítsenek a tolmácsvizsgákon. 


\section{Irodalom}

AIIC 1994. Profile of the Conference Interpreter. AIIC Bulletin. Vol. 22. No. 3.

AIIC. 2002. Interpreter workload study - full report. Letölthető: http://aiic.net/p/657 (Letöltés dátuma: 2019. március 28.)

Alexieva, B. 1993. The Optimum Text in Simultaneous Interpreting: A Cognitive Approach to Interpreter Training. In: Dollerup, C., Loddegaard, A. (eds) Teaching Translation and Interpreting: Training Talent and Experience. Amsterdam-Philadelphia, John Benjamins. 221-229.

Alexieva, B. 1994. Types of texts and intertextuality in simultaneous interpreting. In: Snell Hornby, M., Pöchhacker, F., Kaindl, K. (eds) Translation Studies - an Interdiscipline. Selected papers from the Translation Studies Congress, Vienna, 9-12 September 1992. Amsterdam/Philadelphia: John Benjamins Publishing Company. 179-187.

Alexieva, B. 1999. Understanding the source language text in simultaneous interpreting. The Interpreters' Newsletter No. 9. 45-59

Altman, J. 1994. Error analysis in the teaching of simultaneous interpreting: A pilot study. In: Lambert, S., Moser-Mercer, B. (eds) Bridging the Gap. Amsterdam/ Philadelphia: John Benjamins Publishing Company. 25-38.

Atkinson, J. W. 1957. Motivational determinants of risk-taking behaviour. Psychological Review Vol. 64. No. 6. 359-372.

Bakti M. 2009. Relevanciaelmélet a gyakorlatban. Néhány gondolat a pragmatika és a szinkrontolmácsolás kapcsolatáról. In: Lendvai E. (szerk.) Translatologia Pannonica I. Pécs: PTE BTK Fordítástudományi Kutatóközpont, Szláv Filológia Tanszék. $16-23$.

Barik, H.C. 1975. Simultaneous Interpretation: Qualitative and Linguistic Data. Language and Speech Vol. 18. No. 3. 272-297.

Boronkay-Roe Zs. 2006. A tolmácsolás és a stressz. A magyar fordítók és tolmácsok napja. Budapest. ELTE BTK Fordító- és Tolmácsképző Központ, 2006. március 23-24. Előadás letöltető: https://slideplayer.hu/slide/2823984/ (Letöltés dátuma: 2019.03.28.)

Bühler, H. 1986. Linguistic (semantic) and extralinguistic (pragmatic) criteria for the evaluation of conference interpretation and interpreters. Multilingua Vol. 5. No. 4. 231-235.

Cooper, C.L. et al. 1982. Interpreting stress: Sources of job stress among conference interpreters. Multilingua Vol 1. No.1-2. Amsterdam: Mouton. 97-107.

Csíkszentmihályi M. 2008. Flow. The Psychology of Optimal Experience. New York: Harper Perennial.

Daró, V. 1994. Non-Linguistic Factors Influencing Simultaneous Interpretation. In: Lambert, S., Moser-Mercer, B. (eds) Bridging the Gap. Amsterdam/Philadelphia: John Benjamins Publishing Company. 248-271.

G. Láng Zs. 2002. Tolmácsolás felsőfokon. A hivatásos tolmácsok képzéséröl. Budapest: Scholastica.

Gile, D. 1994. Methodological Aspects of Interpretation and Translation Research. In: Lambert, S., Moser-Mercer, B. (eds) Bridging the Gap. Empirical Research in Simultaneous Interpretation. Amsterdam/Philadelphia: John Benjamins Publishing Company. 39-56.

Gile, D. 1995/2009. Basic Concepts and Models for Interpreter and Translator Training. Amsterdam/Philadelphia: John Benjamins Publishing Co. 
Gillies, A. 2004. Conference Interpreting: A New Students' Companion. Cracow: Tertium Horváth I., Szabari K., Volford K. (szerk.) 2000. Forditás és tolmácsolás a világban. Oktatási segédanyag fordító- és tolmácsképző intézetek hallgatói számára. Budapest: ELTE FTK.

Horváth I. (szerk.) 2015. Bevezetés a tolmácsolás pszichológiájába. Budapest: ELTE Eötvös Kiadó.

Horváth I. 2017. What does sport psychology have to offer interpreting? Babel Vol 63. No. 2. 230-250.

Jantsits Á. 2013. Az értékelés szerepe a tolmácsolás oktatásában. In: Klaudy, K. (szerk.) Forditás és tolmácsolás a harmadik évezred elején. Budapest: ELTE Eötvös Kiadó.

Kahane, E. 2000. Thoughts on the quality of interpretation. Letölthető: https:/aiic.net/ page/197/thoughts-on-the-quality-of-interpretation/lang/1. (Letöltés dátuma: 2019.03.28.)

Kalina, S. 2000. Interpreting competences as a basis and a goal for teaching. The Interpreters' Nerwsletter No. 10. 3-32.

Kalina, S. 2002. Quality in interpreting and its prerequisites: A framework for a comprehensive view. In Garzone, G., Viezzi M. (eds) Interpreting in the 21st Century: Challenges and opportunities. Amsterdam/Philadelphia: John Benjamins. 121-130.

Kalina, S. 2005. Quality Assurance for Interpreting Processes. Meta. Vol. 50. No. 2. $768-784$

Klaudy K. 2005. A fordítási hibák értékelése az életben, a képzésben és a vizsgán. Fordítástudomány VII. évf. 1. szám. 76-84.

Klonowitz, T. 1994. Putting one's Heart into Simultaneous Interpretation. In: Lambert, S., Moser-Mercer, B. (eds) Bridging the Gap. Amsterdam/Philadelphia: John Benjamins Publishing Company. 213-224.

Korpal, P. 2016. Interpreting as a stressful activity: Physiological measures of stress in simultaneous interpreting. Poznań Studies in Contemporary Linguistics. Vol. 52. No. 2. 297-316.

Kurz, I. 2002. Physiological stress responses during media and conference interpreting. In: Garzone, G., Viezzi, M. (eds) Interpreting in the 21st Century: Challenges and opportunities. Benjamins Translation Library 43. 195-202.

Kutz, W. 2005. Zur Bewertung der Dolmetschqualität in der Ausbildung von Konferenzdolmetschern. Lebende Sprachen. Vol 50. No.1. 14-34.

Liu, M., Chiu, Y. 2009. Assessing source material difficulty for consecutive interpreting. Quantifiable measures and holistic judgment. Interpreting Vol. 11. No. 2. 244-266.

Mead, P. 2015. Input Variables. In: Routledge Encyclopedia of Interpreting Studies. London \& New York: Routledge. 191-192.

Moser, P. (ed.) 1995. Survey on expectations of users of conference interpretation. Final report January 1995. AIIC (International Association of Conference Interpreters). https://aiic.net/page/736.

Mack, G. 2002. New perspectives and challenges for interpretation: The example of television. In: Garzone, G, Viezzi, M. (eds) Interpreting in the 21st Century. Amsterdam/Philadelphia: John Benjamins Publishing Company.

Moser-Mercer, B. 1994. Paradigms gained or the art of productive disagreement, In: Lambert, S., Moser-Mercer, B. (eds) Bridging the Gap. Amsterdam/Philadelphia: John Benjamins Publishing Company.

Moser-Mercer, B. 1996. Quality in interpreting: Some methodological issues. The Interpreters' Newsletter No. 7. 43-55.

Moser-Mercer, B. et al. 1998. Prolonged turns in interpreting: Effects on quality, physiological and psychological stress (Pilot study). Interpreting Vol. 3. No. 1. 47-64 
Mouzourakis, P. 1996. Videoconferencing: Techniques and challenges. Interpreting. Vol. 1. No. 1. 21-38.

N. Kollár K., Szabó É. 2004. Pszichológia pedagógusoknak. Budapest: Osiris Kiadó.

Pöchhacker, F. 1994. Quality assurance in simultaneous interpreting. In: Dollerup, C., Lindegaard, A. (eds) Teaching Translation and Interpreting 2: Aims, Insights, Visions. Amsterdam/Philadelphia: John Benjamins. 233-242.

Pöchhacker, F. 2004. Introducing Interpreting Studies. London: Routledge.

Sarason, S.B. 1950. The test-situation and the problem of prediction. Fournal of Clinical Psychology Vol. 6. 387-392.

Schjoldager A. 1996. Empirical Investigations into Simultaneous Interpreting Skills: Methodological and Didactic Reflections. Perspectives Vol. 2. 187-195.

Shlesinger, M. 1997. Quality in simultaneous interpreting. In: Gambier, Y., Gile, D., Taylor C. (eds) Conference Interpreting: Current Trends in Research. Amsterdam/Philadelphia: John Benjamins. 123-131.

Selye J. 1976. Stressz distressz nélkül. Budapest: Akadémiai Kiadó.

Setton, R. 1999. Simultaneous Interpretation, A cognitive-pragmatic analysis. Amsterdam/ Philadelphia: John Benjamins Publishing Company.

Setton, R., Dawrant, A. 2016. Conference Interpreting. A Trainer's Guide. Amsterdam/ Philadelphia. John Benjamins Publishing Company.

Smith, J. C. 1993. Understanding Stress and Coping. New York: Macmillan Publishing Company.

Válóczi M. 2010 A tolmácsoláshoz szükséges képességek és a tolmács-személyiség alakulása napjainkban. Képességfejlesztés a tolmácsolás-gyakorlat órán. BGF Tudományos Évkönyv 2010.

Viaggio, S. 1996. Elementary, my dear Colleague! Educating our students' guesses. The Interpreters' Nezwsletter No. 7. 57-72.

Vuorikoski, A.-R. 2004. A Voice of Its Citizens or a Modern Tower of Babel? The Quality of Interpreting as a Function of Political Rhetoric in the European Parliament. Tampere University Press.

Zeier, H. 1997. Psychophysiological stress research. Interpreting Vol. 2. No. 1-2. 231249. 